\title{
CHEMICAL SOIL FERTILITY DIAGNOSIS FOR COTTON CROPPING IN NORTHERN COTE D'IVOIRE
}

\author{
Diomandé Loua Barthélémy ${ }^{* 1} \bowtie$, Soro Gaoussou Roger ${ }^{2}$, Soro Sibirina ${ }^{3}$, et Yao-Kouamé Albert ${ }^{4}$ \\ 1,3 Institut de Gestion Agropastorale, Filière Economie et Gestion Agropastorale, Université Peleforo Gon \\ Coulibaly de Korhogo, BP 1328 Korhogo, Côte d'Ivoire. \\ ${ }^{2}$ ONG Animation Rurale de Korhogo (ARK), BP 150 Korhogo, Côte d'Ivoire. \\ ${ }^{4}$ Université Félix Houphouët-Boigny d'Abidjan, UFR des Sciences de la Terre et des Ressources Minières, \\ Département des Sciences du sol, 22 BP 582 Abidjan 22, Côte d'Ivoire
}

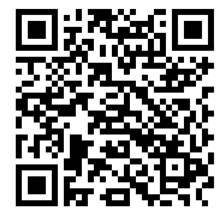

\begin{abstract}
The work was conducted in the north of Cote d'Ivoire, central pivot cotton production savannah area, to make the diagnosis of soil fertility for cotton cropping. Cotton cropping, the mainstay of the savannah's economy, suffered from low productivity in relation to the soil's chemical properties. Prior cultivation, soils samples were collected at a depth of 0 to $30 \mathrm{~cm}$, collecting 32 simple samples to generate a complete sample. The samples were sent to the soil laboratory to measure the pH unities, CEC, nitrogen, phosphorus, potassium, calcium, magnesium, sodium, iron, zinc, copper and manganese contents. In order to facilitate the interpretation of analysis results, the nutrients critical level recommended for optimum production of cotton were used. Results showed that soils had $\mathrm{pH}$ ranging from 4.4 to 6.4. On the other hand, the need to add nitrogen, magnesium and phosphorus to the soils and to augment the low carbon, calcium and potassium content. There is the need to search for fertilizer formulations with nitrogen, magnesium phosphorus and calcium for the Cote d'Ivoire cotton belt.
\end{abstract}

Keywords: Cotton, Productivity, Soil, Chemical Fertility, North of Côte D'ivoire

\section{INTRODUCTION}

Cotton (Gossypium hirsutum L.) is the third most important industrial crop of Côte d'Ivoire after cocoa (Theobroma cacao L.) and coffee (Coffea arabica L.). this is a cash crop of global importance especially, to the economies of producing in savannah's smallholder farmers who depend on cotton for their livelihoods. Cotton cropping is one of the main sources of income of the Ivorian economy A. E. Aiwa, 2015. It counts for less than $10 \%$ of the export incomes. Cotton is the third most important cash crop of the country after cocoa and coffee. Cotton cropping is the main economic resource in the savannah area although it has little relative importance at the national level. The fiber production average 100.000 tons per annum, of which 90\% are exported F. Berti, J.P. Pabanel, E. 2006. In on socio-economic hand, cotton production development increases the farmer agricultural incomes in savannah's zone, in particularly, women incomes.

In Côte d'Ivoire, during the 2015-2018 season, cotton covered approximately 357.061 ha, producing 350.280.513 tons'grain, representing 7\% S. Y. Koffi, 2013 of the total annual crop surface with a mean yield of $981 \mathrm{~kg}$ ha-1 COIC, 2021. During the 2020-2021 season, Ivorian Scientists developped a large, highthroughput genetics centre of cotton seedling. In despite of the varieties of highyielding, such Gouassou (4,000 kg / ha), Sicama (4,000 kg / ha) and BLT (3,000 
$\mathrm{kg}$ / ha), new germoplants had produced $1.700 \mathrm{~kg}$ ha-1, 1,400 kg ha-1 and 1,200 $\mathrm{kg}$ ha-1, respectively. Considering the large amounts of fertilizers and pesticidesused, this performance is relatively low compared with major African countries S. Kanté, 2001.

Several reasons have been reported to account for the low cotton productivity on smallholder farms in Côte d'Ivoire. These include low soil fertility as the major cause of yield decline. Low productivity of agriculture in cotton zones still constitute real concerns for the cotton belt economic development. However, accessible information cannot help to distinguish between possible causes such as fertile savannah soils, in areas. To increase these low yields, cotton cropping requires a practical basis into macronutrients (nitrogen, phosphorus and potassium), secondary nutrients (calcium and magnesium) and micronutrients (zinc, iron, manganese, copper and boron). Furthermore, understanding nutrient concentrations is a very useful in assessment of nutrient levels in soils. However, although large fertilization rates have been increasing in north Côte d'Ivoire for the past 10 years, in many cases, this has not resulted in a proportional increase in crop yields FAO, 2015. On the one hand, Diomandé, L. B. K. Brahima, V. T. Etienne, B.T. Tié, A. Yao-Kouamé, 2014 reported that in the savannah zone of Côte d'Ivoire there are mainly acidic soils, where on low pH soils may occur nutrient deficiencies, in particular, among the microelements, copper $(\mathrm{Cu})$, iron $(\mathrm{Fe})$, manganese $(\mathrm{Mn})$ and zinc (Zn) deficiency is the most widespread problem in cashew tree fields, mostly related to acidic soils and soils.

On the other hand, soil fertility status may be diagnosed using chemical procedures in laboratory. Based upon diagnostic results, preliminary recommendations would be formulated. Therefore, it is important to provide to the farmer appropriate in savannah's zone, good recommendations in soil conditions A. Delaunois, 2013., e.g., on a practical basis into macronutrients, secondary nutrients and micronutrients. Based upon soil diagnostic results suggest that cotton yields would be increased if an adequate soil fertility study is implemented. However, there is a lack of information about the nutrient status of soils to facilitate the implementation of better applying fertilizer practices, such as N-P-K-S-B and urea O. G. Ochou, E. N’Guessan, E. Koto, N. Kouadio, Y. Ouraga, K. Téhia et Y. Touré, 2006, FIRCA, La Filière du Progrès-La filière anacarde, 2018 The main aim of this study was to carry out a diagnostic of soil fertility for cotton crop.

\section{MATERIALS AND METHODS}

\subsection{SOIL ANALYSIS}

Prior the tillage, surface $(0-30 \mathrm{~cm})$ soil samples were collected into a grid size of 10-acres using auger. Sampling areas were carried out in Nielle 10.12 Nord and $5.38 \mathrm{~W}$ ), Dassoungbo ( $9.23 \mathrm{~N}$ and 5.46 W) and Niakaramandougou. For all data sets, samples were located purposively and subjectively to represent soil and cotton cropping land use. Soil samples were bulked, air-dried and $2 \mathrm{~mm}$-sieved for analysis. Samples were also collected over each treatment plot. Organic matter (OM) was determined using wet dichromate method, total $\mathrm{N}$ by Kjeldahl method, available $\mathrm{P}$ by molybdenum blue colorimetry. Exchangeable $\mathrm{K}, \mathrm{Ca}$ and $\mathrm{Mg}$ were extracted using ammonium acetate, $\mathrm{K}$ was read on flame photometer and $\mathrm{Ca}$ and $\mathrm{Mg}$ on atomic absorption spectrophotometer. These samples were also analyzed for plant available Zinc $(\mathrm{Zn})$, Copper $(\mathrm{Cu})$, Iron $(\mathrm{Fe})$, Manganese $(\mathrm{Mn})$ following 
Diethylenetriamine Penta-Acetate (DTPA) extraction methodology. Quantification was carried out by Flame Atomic Absorption Spectroscopy (AAS).

\subsection{FIELD EXPERIMENT}

Field experiments were conducted in 2021 at region of Korhogo, central pivot cotton farm in savannah area, Nielle and Dassoungbo (sandy clay) and clay loam soil of Niakaramandougou. Soils were Ferralsols and Gleysols (Nielle and Dassoungbo) L. B. Diomandé, A. Yao-Kouamé, et B. 2016 and Cambisols and Gleysols in the savannah zone of northern Cote d'Ivoire. Sites were cultivated to cotton with application of fertilizer N-P-K-S-B and urea for many years.

\subsection{STATISTICAL ANALYSIS}

Statistical data analysis was performed for the whole range of samples including 30 samples and analyses were carried out in the R environment, R Core Team $[12,13]$. Descriptive statistics were computed on all soil variables at each location.

\section{RESULTS}

The soil chemical properties used for the present work are shown in Table 1 , Table 2,Table 3. The nutrient critical level recommended for optimum production of cotton in Cote d'Ivoire are also shown D. Arrouays, V. Antoni, M. Bardy, A. Bispo, M. Brossard, C. Jolivet, C. Le Bas, M. Martin, N. Saby, N. Schnebelen, E. Villanneau, P. Stengel, Fertilité 2012, A. Assa, 2005.

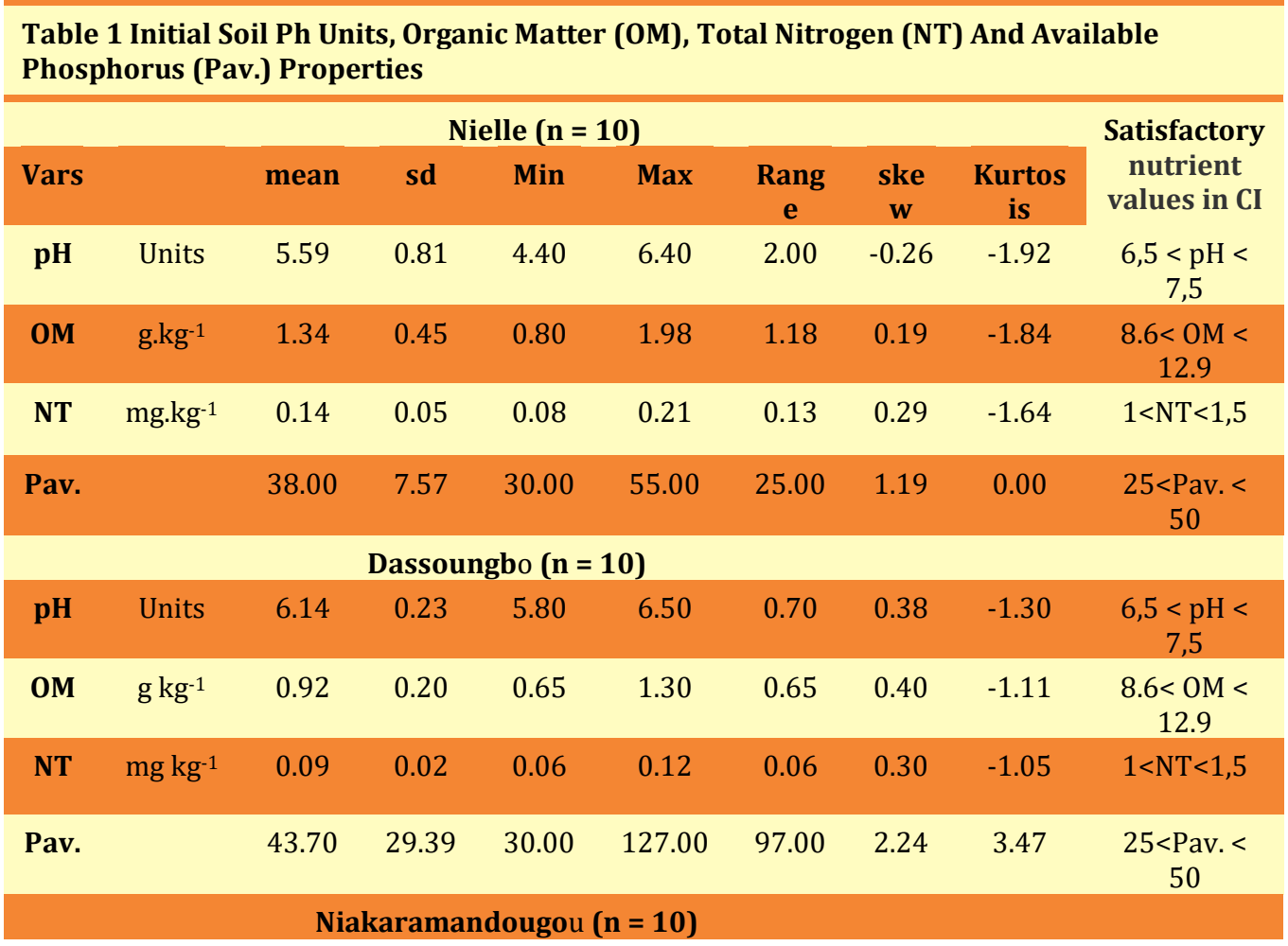


Chemical Soil Fertility Diagnosis for Cotton Cropping in Northern Cote D'ivoire

\begin{tabular}{|c|c|c|c|c|c|c|c|c|c|}
\hline $\mathbf{p H}$ & Units & 6.00 & 0.16 & 5.80 & 6.30 & 0.50 & 0.14 & -1.14 & $\begin{array}{c}6,5<\mathrm{pH}< \\
7,5\end{array}$ \\
\hline $\mathbf{O M}$ & g.kg-1 & 0.92 & 0.28 & 0.45 & 1.32 & 0.87 & -0.11 & -1.40 & $\begin{array}{c}8.6<0 M< \\
12.9\end{array}$ \\
\hline NT & mg.kg-1 & 0.08 & 0.03 & 0.04 & 0.12 & 0.08 & -0.26 & -1.30 & $1<\mathrm{NT}<1,5$ \\
\hline Pav. & & 26.20 & 6.66 & 18.00 & 40.00 & 22.00 & 0.75 & -0.65 & $\begin{array}{c}25<\text { Pav }< \\
50\end{array}$ \\
\hline \multicolumn{10}{|c|}{ TOTAL $(n=30)$} \\
\hline $\mathbf{p H}$ & Units & 5.91 & 0.53 & 4.40 & 6.50 & 2.10 & -1.49 & 1.31 & $\begin{array}{c}6,5<\mathrm{pH}< \\
7,5\end{array}$ \\
\hline $\mathbf{O M}$ & $\mathrm{g} \mathrm{kg}^{-1}$ & 1.06 & 0.38 & 0.45 & 1.98 & 1.53 & 0.92 & 0.16 & $\begin{array}{c}8.6<\mathrm{OM}< \\
12.9\end{array}$ \\
\hline NT & mg kg-1 & 0.10 & 0.04 & 0.04 & 0.21 & 0.17 & 1.17 & 0.90 & $1<\mathrm{NT}<1,5$ \\
\hline Pav & & 35.97 & 18.83 & 18.00 & 127.00 & $\begin{array}{c}109.0 \\
0\end{array}$ & 3.71 & 15.33 & $\begin{array}{c}25<\text { Pav } .< \\
50\end{array}$ \\
\hline
\end{tabular}

Table 2 Summary statistics showing mean values of basic cations (Ca++, $\mathrm{Mg}++, \mathrm{K}+$ and $\mathrm{Na}+$ ) and CEC with the three sites

\begin{tabular}{|c|c|c|c|c|c|c|c|c|}
\hline \multicolumn{8}{|c|}{ Nielle $(n=10)$} & \multirow{2}{*}{$\begin{array}{c}\text { Satisfactory } \\
\text { nutrient } \\
\text { values in } \mathrm{CI}\end{array}$} \\
\hline Vars & mean & sd & Min & Max & Range & skew & Kurtosis & \\
\hline $\mathrm{cmol}_{\mathrm{c}} \mathrm{kg}^{-1}$ & 10.5 & 4.09 & 5 & 17 & 12 & 0.18 & -1.63 & 12 \\
\hline $\mathrm{Ca}^{++}$ & 4.07 & 2.33 & 1.3 & 7.4 & 6.1 & 0.09 & -1.75 & 7.5 \\
\hline $\mathrm{K}^{+}$ & 0.84 & 0.21 & 0.6 & 1.2 & 0.6 & 0.4 & -1.38 & 0.25 \\
\hline $\mathrm{Mg}^{++}$ & 0.34 & 0.19 & 0.1 & 0.6 & 0.5 & 0.27 & -1.82 & 1.33 \\
\hline $\mathrm{Na}^{+}$ & 0.12 & 0.06 & 0.1 & 0.3 & 0.2 & 2.28 & 3.57 & $\mathrm{Na}$ \\
\hline \multicolumn{9}{|c|}{ Dassoungbo $(n=10)$} \\
\hline $\mathrm{cmol}_{\mathrm{c}} \mathrm{kg}^{-1}$ & 7 & 2 & 4 & 10 & 6 & 0 & -1.57 & 12 \\
\hline $\mathrm{Ca}^{++}$ & 1.42 & 0.43 & 1 & 2.2 & 1.2 & 0.69 & -1.04 & 7.5 \\
\hline $\mathrm{K}^{+}$ & 0.87 & 0.17 & 0.7 & 1.2 & 0.5 & 0.54 & -1.18 & 0.25 \\
\hline $\mathrm{Mg}^{++}$ & 0.1 & 0 & 0.1 & 0.1 & 0 & - & - & 1.33 \\
\hline $\mathrm{Na}^{+}$ & 0.05 & 0.05 & 0 & 0.1 & 0.1 & 0 & -2.19 & $\mathrm{Na}$ \\
\hline \multicolumn{9}{|c|}{ Niakaramandougou $(n=10)$} \\
\hline CEC $\quad \mathrm{cmol}_{\mathrm{c}} \mathrm{kg}^{-1}$ & 7.3 & 4.27 & 1 & 14 & 13 & -0.16 & -1.52 & 12 \\
\hline $\mathrm{Ca}^{++}$ & 2.75 & 1.53 & 0.7 & 4.8 & 4.1 & -0.3 & -1.71 & 7.5 \\
\hline $\mathrm{K}^{+}$ & 0.77 & 0.32 & 0.3 & 1.3 & 1 & -0.05 & -1.17 & 0.25 \\
\hline $\mathrm{Mg}^{++}$ & 0.14 & 0.13 & 0.1 & 0.5 & 0.4 & 2.28 & 3.57 & 1.33 \\
\hline $\mathrm{Na}^{+}$ & 0.2 & 0.16 & 0.1 & 0.5 & 0.4 & 1.1 & -0.64 & $\mathrm{Na}$ \\
\hline \multicolumn{9}{|c|}{ TOTAL $(n=30)$} \\
\hline $\mathrm{CEC} \quad \mathrm{cmol}_{\mathrm{c}} \mathrm{kg}^{-1}$ & 8.27 & 3.83 & 1 & 17 & 16 & 0.28 & -0.44 & 12 \\
\hline $\mathrm{Ca}^{++}$ & 2.75 & 1.92 & 0.7 & 7.4 & 6.7 & 0.89 & -0.31 & 7.5 \\
\hline $\mathrm{K}^{+}$ & 0.83 & 0.24 & 0.3 & 1.3 & 1 & -0.16 & -0.13 & 0.25 \\
\hline $\mathrm{Mg}^{++}$ & 0.19 & 0.17 & 0.1 & 0.6 & 0.5 & 1.5 & 0.64 & 1.33 \\
\hline $\mathrm{Na}^{+}$ & 0.12 & 0.12 & 0 & 0.5 & 0.5 & 2.03 & 3.96 & $\mathrm{Na}$ \\
\hline
\end{tabular}




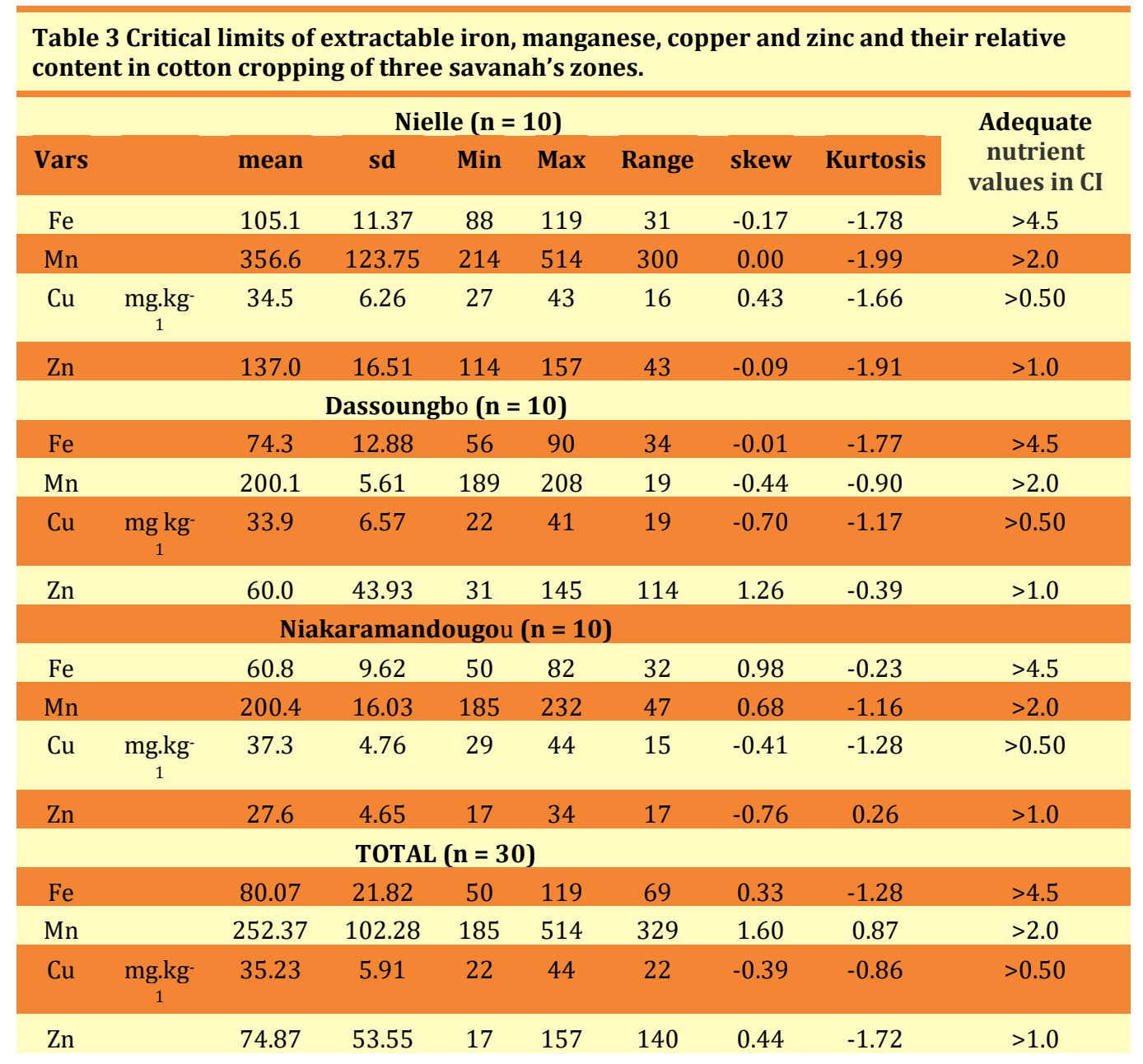

\section{DISCUSSIONS}

The Table 1 summarized the Chemical properties of soils in relation with soil $\mathrm{pH}$, organic matter, nitrogen and available phosphorus. $\mathrm{pH}$ values varied from 4.40 to 6.50 with an average value of $5.91 \pm 0.53$ (Table 1 ). The $\mathrm{pH}$ of soils was acidic due to the indigenous parent material. Low organic matter was observed. The observation of Granite weathering biotite alteration to give iron chlorites and the presence of manganese gravels and pebbles on the soil surface strongly argue in favor of such an acidic soil Diomandé, L. B. S. Soro, D. Koné et K. D. P. 2021. The original composition of biotite has a strong influence on the alteration products Diomandé, L. B. K. Brahima, V. T. Etienne, B.T. Tié, A. Yao-Kouamé, 2014. Organic matter content varied from 0.45 to $1.98 \mathrm{~g} \mathrm{~kg}-1$ with mean value of $1.06 \pm 0.38$ (Table 1). $100 \%$ soil samples had poor SOM content.

The main reason for low organic matter in the area is sudanese temperature which exceeds to $35^{\circ} \mathrm{C}$ due to which rate of decomposition is amplified Koné, B. S. Diatta, S. Oikeh, Y. Gbalou, M. Camara, D. D. Dohm, et A. Assa, 2015. Available total nitrogen $(\mathrm{N})$ contents ranged from 0.04 to $0.21 \mathrm{mg} \mathrm{kg}-1$ with the mean value of 0.10 \pm 0.04 . According to criteria suggested (Table 1), $100 \%$ samples were found low. 
Plant available phosphorous content was deficient in $20 \%$ of the analyzed samples, while $80 \%$ was categorized in satisfactory range L. B. Diomandé, O. F. Akotto, C. Kanko, V. E. Tia, and A. Yao-kouamé, 2015. Phosphorous content ranged from 18.00 to $127.00 \mathrm{mg} \mathrm{kg}-1$ with mean value of $35.97 \pm 18.83$. Low organic matter in soils of surveyed area is the main reason for deficiency of nitrogen. Phosphorous deficiency in acidic soils developed from sandstone $\mathrm{pH}$ approaches 6, precipitations as calcium compounds begins, at $\mathrm{pH} 6.5$ the formation of insoluble calcium salt is a factor in rendering the phosphorus unavailable T. V. Ouattara, K. E. Kassin, L. J. Koko, G. N. Tahi, M. E. Assi, G. Amari, E. Dick, et M. 2017.

This is the place to draw attention to the fact that in an acidic soil, phosphorus, potassium, calcium, magnesium, sulfur and molybdenum are less easily available, while iron, manganese, boron, copper and zinc will be more. It is also known that most plants have optimal growth when the soil $\mathrm{pH}$ varied from 6 to 7 (majority of nutrients are available in this $\mathrm{pH}$ zone).

Results of mean values of basic exchangeable cations ( $\mathrm{Ca}++, \mathrm{Mg}++, \mathrm{K}+$ and $\mathrm{Na}+$ ) and CEC their standard deviation (SD), are shown in table 2. Soil samples are shown low values of exchangeable $\mathrm{Ca}++$ and $\mathrm{Mg}++$ are recorded at the locations. Possible reasons for low values could be that the parent material on which soil has developed is poor in bases and the low pH values in these soil types Quesada, C. A. J. Lloyd1, L. O. Anderson, N. M. Fyllas, M. Schwarz, C. I. Czimczik, 2011Kopittke et Menzies, 2005. High value of exchangeable $\mathrm{K}+$ was recorded at the locations. Cation exchange capacity of soil is a total sum of exchangeable cations that it can adsorb at a specific $\mathrm{pH}$. Results are shown low Soil CEC with an average value of $8.27 \pm 3.83$ (Table 2). At the three locations it is observed that the values of CEC are relatively low in relation to the of basic exchangeable cations $\mathrm{Ca} 2+$ and $\mathrm{Mg} 2+$, specially, soil texture is one of the parameters that have great influence on CEC values Tomašić, M. Tु. Zgorelec, A. Jurišić, I Kisić, 2013.

Results showed Fe content ranged from 50 to $119 \mathrm{mg} \mathrm{Fe} / \mathrm{Kg}$ soil with mean value of $80.07 \pm 21.82 \mathrm{mg} \mathrm{Fe} / \mathrm{Kg}$ (Table 3). Manganese concentration ranged from 185 to $554 \mathrm{mg} \mathrm{Mn} / \mathrm{Kg}$ soil with mean value of $252.37 \pm 102.28$ (Table 3). Plant available $\mathrm{Cu}$ ranged from 22 to $44 \mathrm{mg} \mathrm{Cu} / \mathrm{Kg}$ soil with mean value of $35.23 \pm 5.91$. Zinc concentration ranged from 17 to $157 \mathrm{mg} \mathrm{Zn/} \mathrm{Kg} \mathrm{soil} \mathrm{with} \mathrm{mean} \mathrm{value} \mathrm{of} 74.87$ \pm 53.55 (Table 3 ). All soil samples (100\%) were in adequate category. The possible reason of adequate availability of $\mathrm{Zn}$ in the study area could be the normal nature of its soils. The soils of Korhogo are free from sodicity problem. Soil pH is in acidic range and did hamper micronutrients availability B. Koulibaly, 2011. This acidic pH reduces the solubility of micronutrients in soil solution resultantly micronutrients precipitate and become unavailable to cotton plants.

\section{CONCLUSIONS AND RECOMMENDATIONS}

In this investigation, it is observed that the values of Organic matter, CEC, nitrogen, phosphorus, potassium, calcium, magnesium are very low. However, in this investigation a very high concentration had recorded for iron, zinc, copper and manganese contents. pH for all examined soils was acid. $\mathrm{pH}$ had an impact on soil depending on acidity. The level of organic matter in the soil is relatively low, and its rapid mineralization, in a context of predominantly sandy soil, does not always make available the nutrients that plants need at certain critical phases of their development. It is recommended to have an organic matter content of at least $5 \%$. It is therefore necessary to add, in several batches, about $25 \mathrm{Kg} / \mathrm{m}^{2}$ of compost in order to approach $5 \%$. 


\section{REFERENCES}

A. Assa, 2005. Précis de pédologie à l'usage des étudiants du second cycle des études universitaires, Editions Universitaires, Abidjan, Côte d'Ivoire,92.

A. Delaunois, 2013. Guide pour la description et l'évaluation de la fertilité des sols, Chambre d'agriculture du Tarn et INRA de Montpellier, 39. Retrived from https://tarn.chambreagriculture.fr/fileadmin/user_upload/Occitanie/074_ Inst-Tarn/4

AGROENVIRONNEMENT/Ecophyto/agriculture_conservation/Observer_le _Sol/GUIDE_OBSERVATION_SOL_CA81.pdf

A. E. Aiwa, 2015. L'impact de la culture du coton sur le developpement socioeconomique: etude de cas de la region de korhogo, au nord de la Cote d'Ivoire. Revue baobab $\mathrm{n}^{\circ}$ 17, 2260-269. Retrived from https://www.revuebaobab.org/images/pdf/baobab17/article18.pdf

B. Koulibaly, 2011. Caractérisation de l'acidification des sols et gestion de la fertilité des agrosystèmes cotonniers au Burkina, Thèse de doctorat, Université de Ouagadougou, Mali, $285 . \quad$ Retrived from https://agritrop.cirad.fr/563855/1/document_563855.pdf

COIC, 2021. Rapport d'activité annuel de la Compagnie Ivoirienne de Coton, Korhogo, Côte d'Ivoire, 36.

D. Arrouays, V. Antoni, M. Bardy, A. Bispo, M. Brossard, C. Jolivet, C. Le Bas, M. Martin, N. Saby, N. Schnebelen, E. Villanneau, P. Stengel, Fertilité 2012 des sols : conclusions du rapport sur l'état des sols de France, "Innovations Agronomiques", vol. 21, 1-11. Retrived from https://www.documentation.ird.fr/hor/fdi:010057956

Diomandé, L. B. S. Soro, D. Koné et K. D. P. 2021 Adingra, Diagnostic de la fertilité chimique des sols sous anacarderaies (Anacardium occcidentale L.) dans le département de Korhogo au nord de la Côte d'Ivoire), International Journal of Innovation and Scientific Research, Vol. 53 No. 1, Feb. 50-60. Retrived from http://www.ijisr.issr-journals.org/abstract.php?article=IJISR-20-33602

Diomandé, L. B. K. Brahima, V. T. Etienne, B.T. Tié, A. Yao-Kouamé, 2014 Occurrence and leave extractable essential oil of Lippia multiflora M. (Verbenaceae) as affected by soil acidity, carbon, nitrogen and phosphorus contents in north Côte d'Ivoire, Environment and Natural Resources Research, vol. 4, no. 2, 115-127. Retrived from http://dx.doi.org/10.5539/enrr.v4n2p115

F. Berti, J.P. Pabanel, E. 2006 Canal-Forgues, C. P. Amani, S. Banba, Z. H. Sery, Elaboration d'une stratégie sectorielle coton : perspectives à moyen et long termes-diagnostic et propositions d'orientation, Rapport diagnostic final, Côte d'Ivoire, p.144. Retrived from https://eeas.europa.eu/archives/delegations/cote_ivoire/documents/mor e_info/rapport_diagnostic_final_fr.pdf

FA0, 2015 Mesurer la durabilité des systèmes de culture du coton. Division de la production végétale et de la protection des plantes de la FAO, Comité 
consultatif International du coton Rome, p.177. Retrived from http://www.fao.org/3/a-i4170f.pdf

FIRCA, La Filière du Progrès-La filière anacarde, 2018. Magazine d'information du Fonds Interprofessionnel pour la Recherche et le Conseil Agricoles, Acte 20. [Online] Retrived from https://firca.ci/wpcontent/uploads/2019/05/LaFiliereDuProgres20.pdf (20 juillet 2021).

Koné, B. S. Diatta, S. Oikeh, Y. Gbalou, M. Camara, D. D. Dohm, et A. Assa, 2015 "Estimation de la fertilité potentielle des ferralsols par la couleur: usage de la couleur en morphopédologie", Canadian Journal of Soil Science, vol. 89, no.3, 331-342, Retrived from http://dx.doi.org/10.4141/CJSS07119

Kopittke et Menzies, 2005P. M. Kopittke and N.W Menzies, "Effect of pH on $\mathrm{Na}$ induced Ca deficiency", Plant and soil, vol. 269, 2005, 119-129.

L. B. Diomandé, A. Yao-Kouamé, et B. 2016 Koné, Types de sol et chémotypes d’huile essentielle de Lippia multiflora. E-book, Editions Universitaires Européennes, 171. Retrived from https://www.decitre.fr/livre-pod/typesde-sol-et-chemotypesdhuile-essentielle-de-lippia-multiflora9783841671455.html (20 juillet 2021)

L. B. Diomandé, O. F. Akotto, C. Kanko, V. E. Tia, and A. Yao-kouamé, 2015 "Occurrence and chemical composition of essential oil from Lippia multiflora M. (Verbenaceae) leaves as affected by soil carbon, nitrogen and phosphorus contents in the centre Côte d'Ivoire", International Journal of Agricutural Policy and Research, vol. 3, no. 1, 44-52, Retrived from http://dx.doi.org/10.15739/IJAPR.025

O. G. Ochou, E. N’Guessan, E. Koto, N. Kouadio, Y. Ouraga, K. Téhia et Y. Touré, 2006. Bien produire du coton en Côte d'Ivoire. Fiche technique coton $\mathrm{n}^{\circ} 1$. Centre national de recherche agronomique (CNRA), p.4. Retrived from https://portal.wiktrop.org/biodiv/content/documents/document8b6da06f-39fd-4cd6-93c1-1bc494b42aac/761.pdf

Quesada, C. A. J. Lloyd1, L. O. Anderson, N. M. Fyllas, M. Schwarz, C. I. Czimczik, 2011. Soils of Amazonia with particular reference to the RAINFOR sites, Biogeosciences, 8, 1415-1440. Doi :10.5194/bg-8-1415-2011

R Core Team R (2019) A Language and Environment for Statistical Computing, R Foundation for Statistical Computing, Vienna, Austria, available at: Retrived from http://www.R-project.org.

R Studio Team, RStudio (2018) Integrated Development Environment for R, RStudio, Inc., Boston, MA.

S. Kanté, 2001 Gestion de la fertilité des sols par classe d'exploitation au Mali-Sud. Tropical Resources Management Papers, Wageningen University, 38.

S. Y. Koffi, 2013 Libéralisation de la filière coton en Côte d'Ivoire quinze ans apres: empreinte spatiale et organisationnelle. Cinq Continents, 3(7), 5-17. Retrived from https://nbn-resolving.org/urn:nbn:de:0168-ssoar-359759

T. V. Ouattara, K. E. Kassin, L. J. Koko, G. N. Tahi, M. E. Assi, G. Amari, E. Dick, et M. 2017 Camara, "Effets de la fertilisation organo-phosphatée sur la biodisponibilité du phosphore, la teneur en aluminium et le $\mathrm{pH}$ des sols sous cacaoyers dans la région de Divo en Côte d'Ivoire", Journal of Applied Biosciences, vol.118, 11754-11767. Retrived from https://dx.doi.org/10.4314/jab.v118i1.2 
Tomašić, M. T. Zgorelec, A. Jurišić, I Kisić, 2013 Cation Exchange Capacity of Dominant Soil Types in the Republic of Croatia, Journal of Central European Agriculture, 14(3), 937-951. DOI : 10.5513/JCEA01/14.3.1286 